\title{
PENINGKATAN KUALITAS PERKULIAHAN PADA MATA KULIAH PENGANTAR ILMU SASTRA DENGAN PENDEKATAN SAINTIFIK*
}

\author{
Hartono, Ahmad Wahyudin, Else Liliani, Nurhidayah, dan Dwi Hanti Rahayu \\ Fakultas Bahasa dan Seni UNY \\ E-mail: hartono-fbs@uny.ac.id
}

\begin{abstract}
ABSTRAK
Implementasi lesson study pada perkuliahan Pengantar Ilmu Sastra bertujuan untuk meningkatkan kualitas perkuliahan dengan menggunakan pendekatan saintifik. Sumber data adalah 46 orang mahasiswa kelas B peserta mata kuliah Pengantar Ilmu Sastra 2014/2015 di Jurusan Pendidikan Bahasa dan Sastra Indonesia Fakultas Bahasa dan Seni Universitas Negeri Yogyakarta. Implementasi dilaksanakan dalam empat siklus, masing-masing siklus terdiri atas tahapan plan, do, dan see. Teknik pengumpulan data yang digunakan adalah pengamatan dengan instrumen lembar pengamatan dan dokumentasi berupa foto dan video. Data dianalisis secara deskriptif kualitatif. Hasil implementasi menunjukkan bahwa pendekatan saintifik dalam lesson study dapat meningkatkan kualitas perkuliahan pada mata kuliah Pengantar Ilmu Sastra di kelas B 2014/2015. Dalam perkuliahan, mahasiswa menjadi lebih aktif, suasana perkuliahan menjadi lebih kondusif, diskusi kelompok dalam pendekatan saintifik menjadi lebih hidup karena semua anggota kelompok mempersiapkan materi diskusi dengan baik. Tahapan lima M dalam pendekatan saintifik secara keseluruhan dapat meningkatkan peran aktif setiap mahasiswa dalam proses perkuliahan. Mereka juga menjadi lebih antusias dan aktif dalam setiap pembelajaran. Perkuliahan yang dilakukan juga dapat meningkatkan karakter jujur, tanggung jawab, disiplin, kerja keras, dan kreatif. Dengan kualitas perkuliahan yang lebih baik, pemahaman mahasiswa terhadap proses perkuliahan di perguruan tinggi menjadi baik dan pemahaman materi perkuliahan juga menjadi lebih baik.
\end{abstract}

Kata kunci: pendekatan saintifik, lesson study, kualitas perkuliahan

\section{THE IMPROVEMENT OF THE QUALITY OF LECTURES IN INTRODUCTION TO LITERATURE COURSE BY USING SCIENTIFIC APPROACH}

\begin{abstract}
The implementation of lesson study in Introduction to Literature Course intends to improve the quality of lectures by using scientific approach. The data source was 46 students of class B in the academic year of 2014/15 in Introduction to Literature Course in Indonesian Language and Literature Department of the Faculty of Languages and Arts of Yogyakarta State University. The research was conducted in four cycles using the step of planning, doing, and seeing. The data collection technique was conducted by observation using observation sheets and by documentation in the form of photos and videos. The data were then analyzed by using descriptive-qualitative method. The results show that scientific approach can improve the quality of lectures in Introduction to Literature course in Class B of the academic year of 2014/15. In the class, students were more active, the academic atmosphere was more conducive, and group discussions were also more dynamic because all members of the groups had prepared all the discussion materials well. The five stages in scientific approach could improve the students' performance in the class. They became more enthusiastic and active in each learning, and the lectures could also improve the character of being honest, responsible, disciplined, hard-working, and creative. With all
\end{abstract}


these improved lectures, students' comprehension of the lecturing process and materials could be better.

Keywords: scientific approach, lesson study, the quality of lectures

\section{PENDAHULUAN}

Mata kuliah Pengantar Ilmu Sastra merupakan salah satu mata kuliah wajib bagi mahasiswa jurusan Pendidikan Bahasa dan Sastra Indonesia.Mata kuliah ini merupakan mata kuliah dasar yang berisi materi-materi dasar terkait ilmu sastra yang harus dikuasai mahasiswa sebagai dasar untuk mempelajari materi sastra lebih lanjut.Mata kuliah ini merupakan mata kuliah dasar yang berisi materi-materi dasar terkait ilmu sastra yang harus dikuasai mahasiswa sebagai dasar untuk mempelajari materi sastra lebih lanjut. Mata kuliah ini dalam Kurikulum Jurdik Bahasa dan Sastra Indonesia diberikan pada semester satu.

Mahasiswa semester satu belum bisa mengikuti perkuliahan secara maksimal. Mereka masih perlu melakukan penyesuaian terutama dalam hal strategi belajar di perguruna tinggi. Ada beberapa masalah yang sering dialami mereka terkait kuliahnya. Beberapa masalah tersebut antara lain, konsentrasi, starategi belajar, keberanian dan rasa percaya diri, keaktifan, dan merasa kurang mampu.

Permasalahan tersebut juga dialami mahasiswa semester satu di Jurusan Pendidikan Bahasa dan Sastra IndonesiaFBS UNY yang mengambil mata kuliah Pengantar Ilmu Sastra. Untuk itu, perlu dicarikan alternatif pemecahannya. Salah satu cara yang bisa dilakukan adalah dengan menerapkan pendekatan saintifik pada mata kuliah tersebut. Dengan pendekatan saintifik, diharapkan permasalahan-permasalahan tersebut dapat diatasi sehingga mahasiswa dapat belajar dengan baik dan akhirnya mereka akan berhasil dalam kuliahnya.

Selain itu, dalam perkuliahan tersebut juga dilakukan lesson study. Lesson study merupakan pembinaan profesi pendidik melalui pengkajian pembelajaran secara kolaboratif dan berkelanjutan berdasarkan prinsip-prinsip kolegalitas dan mutual learning untuk membangun learning community. Lesson study dapat dimaknai sebagai belajar bersama dari suatu pembelajaran yang dilakukan baik pada pembe- lajaran oleh diri sendiri, maupun pembelajaran orang lain, mulai dari persiapan sampai pelaksanaan pembelajaran dan melakukan refleksi terhadap pembelajaran tersebut (Sukirman, 2013). Dengan kegiatan lesson study diharapkan dapat dikembangkan model-model pembelajaran efektif untuk sejumlah materi pokok, yang dapat diadopsi, diadaptasi atau dimodifikasi dosen dalam konteks pembelajaran di kelas (Pusat Penjaminan Mutu, 2014:3).

Tujuan penelitian ini untuk meningkatkan kualitas pembelajaran mata kuliah Pengantar Ilmu Sastra.Dengan meningkatnya kualitas pembelajaran tersebut maka kemampuan mahasiswa dalam memahami materi kuliah juga akan meningkat.

\section{METODE}

Subjek yang dikaji sebagai sumber data dalam penelitian ini adalah mahasiswa semester I yang sedang menempuh mata kuliah Pengantar Ilmu Sastra pada semester gasal tahun ajaran 2014/2015. Jumlah mahasiswa peserta kuliah sebanyak 46 orang mahasiswa yang terdiri atas 34 perempuan dan 12 laki-laki. Dua orang di antara mereka adalah mahasiswa yang mengulang. Perkuliahan dilaksanakan setiap hari Kamis pukul 07.30 - 09.10 di gedung GK I ruang 307.

Upaya meningkatkan kualitas pembelajaran dalam mata kuliah Pengantar Ilmu Sastra dilakukan dengan implementasi pendekatan saintifik dalam kegiatan Lesson Study.Pembelajaran dengan pendekatan saintifik adalah pembelajaran yang terdiri atas kegiatan mengamati (untuk mengidentifikasi masalah yang ingin diketahui), merumuskan pertanyaan (dan merumuskan hipotesis), mengumpulkan data/ informasi dengan berbagai teknik, mengolah/ menganalisis data/informasi dan menarik kesimpulan dan mengkomunikasikan hasil yang terdiri atas kesimpulan dan mungkin juga temuan lain yang di luar rumusan masalah untuk memperoleh pengetahuan, keterampilan dan sikap. 
Prinsip-prinsip pembelajaran dengan pendekatan saintifik adalah sebagai berikut. (1) Berpusat pada peserta didik yaitu kegiatan aktif peserta didik secara fisik dan mental dalam membangun makna atau pemahaman suatu konsep, hukum/prinsip; (2) Membentuk students self concept yaitu membangun konsep berdasarkan pemahamannya sendiri;(3) Menghindari verbalisme; (4) Memberikan kesempatan pada peserta didik untuk mengasimilasi dan mengakomodasi konsep, hukum, dan prinsip; (5) Mendorong terjadinya peningkatan kecakapan berpikir peserta didik; (6) Meningkatkan motivasi belajar peserta didik; (7) Memberikan kesempatan kepada peserta didik untuk melatih kemampuan dalam komunikasi; (8) Memungkinkan adanya proses validasi terhadap konsep, hukum, dan prinsip yang dikonstruksi peserta didik dalam struktur kognitifnya; (9) Melibatkan keterampilan proses sains dalam mengonstruksi konsep, hukum, atau prinsip, dan (10) Melibatkan proses kognitif yang potensial dalam merangsang perkembangan intelektual, khususnya keterampilan berpikir tingkat tinggi peserta didik (Kementerian Pendidikan dan Kebudayaan, 2014:4).

Implementasi lesson study pada mata kuliah tersebut dilaksanakan dalam empat siklus. Setiap siklus terdiri atas plan, do, see (Sukirman, 2013). Plan adalah merencanakan, yakni merencanakan tindakan yang akan dilakukan dan berbagai alat atau sarana yang dibutuhkan. Plan dilaksanakan dengan cara berdiskusi antara guru atau dosen model dengan anggota kelompok yang menjadi calon pengamat. Do adalah implementasi atau pelaksanaan pembelajaran hasil dari plan yang telah dilakukan sebelumnya. Pada kegiatan do ini, salah satu dosen menjadi dosen model yang melakukan kegiatan perkuliahan dan empat orang dosen lainnya sebagai pengamat. Para pengamat memberikan komentar, kritik, saran masukan untuk perbaikan kualitas pembelajaran. Pengamatan difokuskan pada mahasiswa dalam mengikuti perkuliahan dan bagaimana dosen model memfasilitasi proses pembelajaran. Kegiatan atau tahap see dilakukan setelah tahap $d o$ atau pelaksanaan perkuliahan. See ini sering juga disebut refleksi, yakni mengkaji dan mengevaluasi fenomena pembelajaran yang terjadi untuk bahan perbaikan pada pembelajaran berikutnya.
Dosen model dalam penelitian ini adalah Hartono, M.Hum. pengampu mata kuliah Pengantar Ilmu Sastra. Empat orang dosen yang lain sebagai pengamat, yaitu Else Liliani, S.S., M.Hum., Nurhidayah, M.Hum., Akhmad Wahyudin, M.Hum,. dan Dwi Hanti Rahayu, M.Pd. Pengumpulan data dilakukan dengan mengamati proses pembelajaran yang difokuskan pada mahasiswa. Selain itu, juga digunakan teknik dokumentasi dalam mengumpulkan data dengan foto dan video. Data yang telah dikumpulkan berupa hasil pengamatan yang berwujud kalimat-kalimat deskriptif, foto, dan video. Data dianalisis dengan analisis deskriptif kualitatif.

\section{HASIL DAN PEMBAHASAN}

Penelitian ini dilaksanakan dalam empat siklus. Masing-masing siklus terdiri atas kegiatan plan, do, dan see yang dilakukan oleh dosen model dan pengamat.

\section{Pelaksanaan Siklus I \\ Plan}

Plan pada siklus I dilaksanakan pada tanggal 1 dan 7 Oktober 2014. Namun, di antara tanggal tersebut sebenarnya kegiatan plan juga berlangsung. Kegiatan ini dihadiri oleh tim Lesson Study Jurusan Pendidikan Bahasa dan Sastra Indonesia. Pada plan pertama dibicarakan jadwal kegiatan secara menyeluruh, pembagian tugas secara umum. Pada kegiatan plan kedua, disajikan RPP dan perangkat pembelajaran yang lain. RPP dan perangkat pembelajaran tersebut dicermati bersama. Selain dari anggota tim, pada plan kedua ini juga mendapat masukan dari Esti Swatika Sari, M.Hum. dosen pengampu mata kuliah Pengantar Ilmu Sastra terkait penggunaan pendekatan saintifik yang akan digunakan dalam pembelajaran.

\section{Do}

Open lesson yang pertama dilaksanakan pada hari Kamis, 9 Oktober 2014, pada pukul 07.30 - 09.10 di ruang GKI, 307. Dosen model Hartono, M.Hum, dan dosen pengamat Else Liliani, S.S., M.Hum., Nurhidayah, M.Hum., Akhmad Wahyudin, M.Hum., dan Dwi Hanti Rahayu, M.Pd.

Materi kuliah pada open lesson pertama ini adalah unsur-unsur pembangun fiksi. Materi 
disajikan dengan menggunakan pendekatan pembelajaran saintifik dengan lima tahapan, yaitu mengamati, menanya, mengumpulkan informasi, menalar atau mengasosiasi, dan mengomunikasikan. Pada kegiatan Do pertama ini kegiatan saintifik sampai pada tahap ketiga, yaitu mengumpulkan informasi. Pembelajaran dapat berjalan lancar meskipun masih terdapat kekurangan yang masih harus diperbaiki pada pertemuan selanjutnya.

See

Tahapan See dilakukan pada hari Kamis, 9 Oktober 2014 setelah selesai kegiatan Do dihadiri dosen model dan semua dosen pengamat. Berikut ini rangkuman hasil pengamatan yang telah dilakukan pada siklus pertama.

1) Secara umum mahasiswa telah siap mengikuti perkuliahan, meskipun ada beberapa mahasiswa yang kurang siap.

2) Ada mahasiswa yang kurang antusias menanggriapi pertanyaan dari dosen.

3) Ada mahasiswa yang kurang cepat dan tepat dalam menanggapi perintah dosen untuk membentuk kelompok diskusi.

4) Kelompok diskusi yang berada di belakang kerja kelompoknya masih kurang meskipun di dekatnya ada dosen pengamat.

5) Dalam diskusi kelompok masih ada mahasiswa yang bermain HP.

6) Referensi yang dibawa tidak sama untuk setiap kelompok. Ada kelompok yang membawa banyak tetapi ada juga kelompok yang referensinya hanya sedikit.

7) Pembagian tugas dalam kelompok kurang merata.

Dari hasil pengamatan dan refleksi yang telah dilakukan maka disarankan perbaikan untuk kegiatan Do pada pertemuan atau perkuliahan berikutnya. Saran perbaikan tersebut adalah sebagai berikut.

1. Kegiatan apersepsi perlu lebih diintensifkan agar semua mahasiswa siap untuk mengikuti perkuliahan.

2. Tempat duduk kelompok diatur sedemikian rupa sehingga tidak ada yang di belakang sendiri.

3. Dosen model perlu berkeliling lebih sering untuk memantau kegiatan diskusi yang dilakukan mahasiswa.
4. Perlu adanya batas minimal referensi yang harus dibawa oleh mahasiswa dalam setiap kelompok.

5. Perlu adanya pembagian tugas yang jelas dalam kelompok, bagaimana strategi menyelesaikan tugas dalam kelompok.

\section{Pelaksanaan Siklus II \\ Plan}

Tahapan plan atau perencanaan pada siklus kedua dilaksanakan tanggal $10-15$ Oktober 2014. Dalam tahapan plan ini, dosen model dan semua dosen pengamat aktif untuk mempersiapkan tahapan Do pada pertemuan berikutnya. RPP yang telah disusun dicermati kembali semua unsurnya, terutama pada penerapan pendekatan pembelajaran saintifik, media, dan evaluasi. Saran dan masukkan refleksi siklus I diperhatikan untuk dilaksanakan pada siklus kedua.

Perbaikan yang perlu dilakukan pada kegiatan $D o$ kedua di antaranya adalah:

1. Kegiatan apersepsi lebih diintensifkan agar semua mahasiswa siap untuk mengikuti perkuliahan.

2. Tempat duduk kelompok diatur sedemikian rupa sehingga tidak ada yang di belakang sendiri.

3. Dosen model berkeliling lebih sering untuk memantau kegiatan diskusi yang dilakukan mahasiswa.

4. Adanya batas minimal referensi yang harus dibawa oleh mahasiswa dalam setiap kelompok.

5. Adanya pembagian tugas yang jelas dalam kelompok, bagaimana strategi menyelesaikan tugas dalam kelompok.

Do

Open lesson yang kedua dilaksanakan pada hari Kamis, 16 Oktober 2014, pada pukul $07.30-09.10$ di ruang GKI, 307. Dosen model Hartono, M.Hum, dan dosen pengamat Else Liliani, S.S., M.Hum., Nurhidayah, M.Hum., Akhmad Wahyudin, M.Hum,. dan Dwi Hanti Rahayu, M.Pd.

Materi kuliah pada open lesson kedua ini adalah masih melanjutkan materi yang pertama, yaitu unsur-unsur pembangun fiksi. Materi 
disajikan dengan menggunakan pendekatan pembelajaran saintifik dengan lima tahapan, yaitu mengamati, menanya, mengumpulkan informasi, menalar atau mengasosiasi, dan mengomunikasikan. Pada kegiatan Do kedua ini kegiatan saintifik yang dilakukan adalah mengumpulkan informasi dan mengasosiasi atau tahap ketiga dan keempat. Pembelajaran dilaksanakan dengan metode diskusi kelompok dan saling kunjung antarkelompok untuk melakukan kegiatan saling koreksi. Pembelajaran dapat berjalan lancar meskipun masih terdapat kekurangan yang masih harus diperbaiki pada pertemuan selanjutnya.

See

Tahapan See pada tahap kedua ini juga dilakukan pada hari Kamis, 16 Oktober 2014 setelah selesai kegiatan Do. Kegiatan inidihadiri oleh dosen model dan semua dosen pengamat.

Berikut ini rangkuman hasil pengamatan yang telah dilakukan pada siklus kedua.

1. Secara umum mahasiswa telah siap mengikuti perkuliahan, meskipun ada beberapa mahasiswa yang kurang siap.

2. Kelompok diskusi yang berada di belakang, kerja kelompoknya masih kurang meskipun di dekatnya ada dosen pengamat.

3. Dalam diskusi kelompok, masih ada anggota kelompok yang kurang aktif.

4. Dalam diskusi kelompok masih ada mahasiswa yang bermain HP.

5. Pembagian tugas dalam kelompok masih kurang merata.

6. Dalam memberikan komentar atau koreksi hasil kelompok lain, masih ada anggota kelompok yang tidak maksimal kerjanya.

7. Ketika kunjungan antarkelompok, masih ada anggota kelompok yang bermain sendiri dan kurang fokus.

Dari hasil pengamatan dan refleksi yang telah dilakukan maka disarankan perbaikan untuk kegiatan Do pada pertemuan atau perkuliahan berikutnya. Saran perbaikan tersebut adalah sebagai berikut.

1. Kegiatan apersepsi masih perlu lebih diintensifkan.

2. Tempat duduk kelompok masih perlu diatur sedemikian rupa sehingga semua kelompok berada di ruangan dan mudah dimonitor oleh dosen model.

3. Dosen model perlu berkeliling lebih sering untuk memantau kegiatan diskusi yang dilakukan mahasiswa sehingga tidak terjadi lagi mahasiswa yang bermain hp ketika kerja kelompok.

4. Diperlukan strategi agar dalam kunjungan antarkelompok untuk memberikan komentar bisa lebih teratur dan baik.

5. Tugas memberikan komentar dalam diskusi antarkelompok perlu diatur sehingga semua anggota kelompok berkesempatan menyampaikan komentarnya.

6. Perlu adanya pembagian tugas yang jelas dalam kelompok, bagaimana strategi menyelesaikan tugas dalam kelompok terutama dalam menanggapi komentar dari hasil diskusi dengan kelompok lain.

\section{Pelaksanaan Siklus III \\ Plan}

Tahapan plan atau perencanaan pada siklus ketiga dilaksanakan tanggal $17-22$ Oktober 2014. Dalam tahapan plan ini, dosen model dan semua dosen pengamat aktif untuk mempersiapkan tahapan Do pada pertemuan berikutnya. RPP yang telah disusun dicermati kembali semua unsurnya, terutama pada penerapan pendekatan pembelajaran saintifik, media, dan evaluasi. Saran dan masukkan refleksi pada siklus II diperhatikan untuk dilaksanakan pada siklus ketiga.

Perbaikan yang perlu dilakukan pada kegiatan Do ketiga di antaranya adalah:

1. Mengintensifkan kegiatan apersepsi.

2. Menata kembali tempat duduk kelompok sehingga semua kelompok berada di ruangan dan mudah dimonitor oleh dosen model.

3. Lebih mengintensifkan pengawasan yang dilakukan dosen model sehinga diskusi dapat berlangsung dengan lebih baik.

4. Memilih strategi yang tepat sehingga kerja sama antarkelompok dalam memberikan komentar bisa lebih teratur dan baik.

5. Perlu adanya pembagian tugas yang jelas dalam kelompok, bagaimana strategi menyelesaikan tugas dalam kelompok terutama dalam menanggapi komentar dari hasil diskusi dengan kelompok lain. 
Do

Open lesson yang ketiga dilaksanakan pada hari Kamis, 23 Oktober 2014, pada pukul 07.30 - 09.10 di ruang GKI, 307. Dosen model Hartono, M.Hum, dan dua orang dosen pengamat, yaitu Else Liliani, S.S., M.Hum., dan Nurhidayah, M.Hum. Akhmad Wahyudin, M.Hum,. dan Dwi Hanti Rahayu, M.Pd. tidak bisa ikut mengamati pelaksanaan pembelajaran karena ada keperluan keluarga yang tidak bisa ditinggalkan.

Materi kuliah pada open lesson ketiga ini masih melanjutkan materi yang kedua, yaitu unsur-unsur pembangun fiksi. Materi disajikan dengan menggunakan pendekatan pembelajaran saintifik dengan lima tahapan, yaitu mengamati, menanya, mengumpulkan informasi, menalar atau mengasosiasi, dan mengomunikasikan. Pada kegiatan Do ketiga ini kegiatan saintifik yang dilakukan adalah mengomunikasikan hasil diskusi yang telah dilakukan pada siklus kedua. Pembelajaran dilaksanakan dengan diskusi. Masing-masing kelompok mempresentasikan hasil diskusi kelompoknya. Setiap kelompok yang presentasi dipimpin oleh seorang moderator yang diambilkan dari kelompok lain.

See

Tahapan See pada tahap ketiga ini tidak dilakukan pada hari Kamis, 16 Oktober 2014 setelah selesai kegiatan Do sebagaimana pada siklus-siklus sebelumnya karena dosen pengamat yang datang hanya dua orang. Kegiatan see baru dilakukan pada hari Rabu, 29 Oktober 2014 sekaligus melakukan plan untuk siklus keempat. Kegiatan inidihadiri oleh dosen model dan semua dosen pengamat.

Berikut ini rangkuman hasil pengamatan yang telah dilakukan pada siklus ketiga.

1. Mahasiswa telah siap mengikuti perkuliahan.

2. Masih ada anggota kelompok diskusi yang kurang maksimal dalam kerja kelompok.

3. Tidak semua anggota kelompok serius memperhatikan ketika kelompok lain sedang presentasi hasil diskusi kelompoknya.

4. Masih ada anggota kelompok yang kurang maksimal kerjanya, perhatiannya kurang maksimal pada presentasi kelompok.
5. Pembagian kerja dalam presentasi perlu dilakukan diawal perkuliahan.

6. Ruangan perkuliahan kurang representatif, ac tidak berfungsi, terlalu panas.

7. Waktu presentasi masih kurang.

Dari hasil pengamatan dan refleksi yang telah dilakukan maka disarankan perbaikan untuk kegiatan Do pada pertemuan atau perkuliahan berikutnya. Saran perbaikan tersebut antara lain adalah sebagai berikut.

1. Tempat duduk kelompok masih perlu diatur sedemikian rupa sehingga mudah untuk melihat dan mengikuti presentasi dari kelompok yang maju prsentasi.

2. Perlu ada pembagian kelompok yang presentasi dan yang bertugas memberikan pendapat.

3. Dosen model perlu berkeliling lebih sering untuk memantau kegiatan presentasi yang dilakukan antarkelompok mahasiswa sehingga tidak terjadi lagi mahasiswa yang bermain hp ketika kelompok lain sedang presentasi.

4. Diperlukan strategi agar presentasi dapat berjalan dengan baik.

5. Tugas memberikan jawaban dalam presentasi antarkelompok perlu diatur sehingga semua anggota kelompok berkesempatan menyampaikan tanggapannya.

\section{Pelaksanaan Siklus IV \\ a. Plan}

Tahapan plan atau perencanaan pada siklus keempat dilaksanakan lebih lama karena mahasiswa sasaran mengikuti mid semester. Kegiatan ini dilaksanakan tanggal 30 Oktober sampai tanggal 5 November 2014. Dalam tahapan plan ini, dosen model dan semua dosen pengamat aktif untuk mempersiapkan tahapan Do pada pertemuan keempat atau pertemuan $D o$ yang terakhir. RPP yang telah disusun dicermati kembali semua unsurnya, terutama pada penerapan pendekatan pembelajaran saintifik, media, dan evaluasi. Materi yang akan disampaikan pada siklus keempat adalah unsur pembangun puisi, jadi berbeda dengan materi pada siklus I sampai III. Saran dan masukkan refleksi pada siklus III diperhatikan untuk dilaksanakan pada siklus keempat. 
Perbaikan yang perlu dilakukan pada kegiatan $D o$ keempat di antaranya adalah:

1. Tempat duduk kelompok masih perlu diatur sedemikian rupa sehingga mudah untuk melihat dan mengikuti presentasi dari kelompok yang maju prsesntasi.

2. Pengelompokkan perlu dilakukan oleh dosen agar anggota kelompoknya bervariasi atau heterogen dan tidak terjadi teman dekat dalam satu kelompok.

3. Perlu ada pembagian kelompok yang presentasi dan yang bertugas memberikan pendapat.

4. Dosen model perlu berkeliling lebih sering untuk memantau kegiatan presentasi yang dilakukan antarkelompok mahasiswa sehingga tidak terjadi lagi mahasiswa yang bermain hp ketika kelompok lain sedang presentasi.

5. Diperlukan strategi agar presentasi dapat berjalan dengan baik.

6. Tugas memberikan jawaban dalam prsesentasi antarkelompok perlu diatur sehingga semua anggota kelompok berkesempatan menyampaikan tanggapannya.

Do

Open lesson yang keempat dilaksanakan pada hari Kamis, 6 November 2014, pada pukul 07.30 - 09.10 di ruang GKI, 307. Dosen model Hartono, M.Hum, dan empat orang dosen pengamat, yaitu Else Liliani, S.S., M.Hum., Nurhidayah, M.Hum., Dwi Hanti Rahayu, M.Pd., dan Akhmad Wahyudin, M.Hum,. dapat hadir untuk melakukan pengamatan kegiatan perkuliahan yang dilakukan pada siklus IV.

Materi kuliah pada open lesson keempat ini berbeda dengan materi sebelumnya, yaitu materi unsur pembangun puisi. Materi disajikan masih dengan menggunakan pendekatan saintifik dengan lima tahapan, yaitu mengamati, menanya, mengumpulkan informasi, menalar atau mengasosiasi, dan mengomunikasikan. Pada kegiatan Do keempat ini kegiatan saintifik yang dilakukan adalah mengamati, menanya, dan mengumpulkan informasi. Pembelajaran masih dilaksanakan dengan teknik diskusi kelompok. Pembelajaran diawali dengan mahasiswa menyimak tayangan pembacaan puisi berjudul "Kesaksian Akhir Abad" oleh WS. Rendra. Selain menyimak pembacaan puisi, mahasiswa juga dapat membaca naskah puisi tersebut yang dibagikan diawal pembelajaran. Mahasiswa aktif mengikuti pembelajaran dari awal sampai akhir.

\section{See}

Tahapan See pada tahap keempat ini dilaksanakan langsung setelah tahapan Do yang dilakukan pada hari itu juga, yaitu Kamis, 6 November 2014. Kegiatan yang berlangsung di ruang GK I, 307 ini dihadiri oleh dosen model dan semua dosen pengamat.

Berikut ini rangkuman hasil pengamatan yang telah dilakukan pada siklus keempat.

1. Mahasiswa tampak lebih siap mengikuti perkuliahan.

2. Pembagian kelompok diskusi yang dilakukan secara acak dapat meningkatkan kerjasama antaranggota kelompok sehingga diskusi dapat berjalan lebih baik.

3. Masih ada anggota kelompok diskusi yang kurang maksimal dalam kerja kelompok. Mahasiswa yang kurang maksimal kerjanya tersebut ternyata sama orangnya dari siklussiklus sebelumnya.

4. Perubahan teknik koreksi antarkelompok yang diwakili oleh dua orang anggota kelompok menjadi lebih baik.

5. Tidak semua anggota kelompok serius memperhatikan ketika kelompok lain sedang presentasi hasil diskusi kelompoknya.

6. Ruangan perkuliahan kurang representatif, AC tidak berfungsi maksimal, masih terlalu panas.

\section{Pembahasan}

Pelaksanaan perkuliahan Pengantar Ilmu Sastra dengan pendekatan saintifik melalui kegiatan lesson study secara umum dapat berjalan dengan baik. Mahasiswa peserta perkuliahan merupakan mahasiswa baru, yaitu semester I pada tahun perkuliahan menyesuaikan diri dengan strategi perkuliahan yang diikutinya. Mereka lebih banyak pasif dalam mengikuti perkuliahan.

Melalui kegiatan lesson study dengan menerapkan pendekatan saintifik pada perku- 
liahan ini, mahasiswa dilatih dan diajak untuk selalu aktif dalam setiap proses perkuliahan. Pada siklus pertama pelaksanaan lesson study, para mahasiswa masih kurang aktif, yang sudah bisa aktif baru sebagian kecil. Masih banyak mahasiswa peserta perkuliahan yang belum memahami tugas dan kewajibannya. Ada yang bermain sendiri dan ada juga yang masih membuka HP. Langkah pendekatan saintifik yang dilakukan pada siklus pertama adalah mengamati dan menanya. Walaupun dua tahapan tersebut dilaksanakan melalui kegiatan diskusi kelompok, tetapi peranserta mahasiswa masih belum maksimal. Oleh karena itu, dalam siklus II disarankan untuk (1) melakukan kegiatan apersepsi yanglebih intensif agar semua mahasiswa siap untuk mengikuti perkuliahan, (2) tempat duduk kelompok diatur kembali, (3) dosen model perlu berkeliling lebih sering untuk memantau kegiatan diskusi yang dilakukan mahasiswa, (4) memperbanyak referensi yang harus disiapkan dan dibawa oleh mahasiswa dalam setiap kelompok, dan (5) perlu adanya pembagian tugas yang jelas dalam kelompok, bagaimana strategi menyelesaikan tugas.

Siklus II dilaksanakan dengan memperhatikan dan melaksanakan saran dari siklus pertama. Materi yang dibahas masih sama, melanjutkan materi tentang unsur-unsur fiksi dengan pendekatan saintifik. Pada siklus dua ini tahapan pendekatan saintifik yang dilakukan adalah mengumpulkan informasi dan mengasosiasi atau tahap ketiga dan keempat. Mahasiswa aktif melakukan pengumpulan informasi dan mengasosiasi terkait dengan unsur-unsur fiksi. Pemanfaatan media pada siklus dua ini juga lebih dimaksimalkan sehingga semua peserta dapat berpartisipasi lebih aktif. Pada siklus kedua ini kualitas perkuliahan sudah dapat meningkat tetapi masih belum maksimal karena masih ada mahasiswa yang kurang maksimal dalam kerja kelompok. Karena belum bisa maksimal kualitas perkuliahannya, maka pada siklus ketiga disarankan untuk (1) mengintensifkan apersepsi, (2) tempat duduk kelompok masih perlu diatur sedemikian rupa sehingga semua kelompok berada di ruangan dan mudah dimonitor oleh dosen model, (3) dosen model perlu lebih intensif dalam memantau kerja kelompok, (4) diperlukan strategi agar dalam kunjungan antarkelompok untuk memberikan komentar bisa lebih teratur dan baik, (5) perlu ada pembagian tugas yang jelas dalam kelompok untuk menyampaikan hasil diskusi dan memberikan komentar.

Pada siklus ketiga, perkuliahan masih melanjutkan materi unsur-unsur fiksi dengan tahap saintifik yang kelima, yaitu mengomunikasikan hasil diskusi yang telah dilakukan pada siklus kedua. Perkuliahan masih dilaksanakan dengan diskusi kelompok. Masingmasing kelompok mengomunikasikan hasil kerjanya dengan mempresentasikan hasil diskusi kelompoknya. Pada siklus ketiga ini, kualitas perkuliahan sudah dapat ditingkatkan dengan baik walaupun belum bisa maksimal sesuai harapan dan tujuan perkuliahan. Untuk lebih memaksimalkan kualitas perkuliahan, maka pada siklus keempat disarankan untuk (1) mengatur kembali tempat duduk anggota kelompok, (2) pengelompokkan mahasiswa lebih bervariasi atau heterogen sehingga tidak terjadi teman dekat dalam satu kelompok, (3) pembagian tugas dalam kelompok perlu diperhatikan lagi, (4) pengawasan dari dosen model lebih diintensifkan, (5) pelaksanaan presentasi hasil diskusi lebih diintensifkan. Dengan saran perbaikan tersebut diharapkan setelah selesai siklus keempat kualitas perkuliahan menjadi lebih baik dan meningkat.

Siklus keempat dilaksanakan dengan materi baru, yaitu unsur pembangun puisi. Perkuliahan masih menggunakan pendekatan saintifik dan pada siklus empat ini tahapan yang dilakukan mengamati, menanya, dan mengumpulkan informasi. Berbeda dengan siklus-siklus sebelumnya, pada siklus ini mahasiswa sudah bisa aktif dalam proses perkuliahan. Tahapan pendekatan saintifik mulai dari mengamati unsur pembangun puisi, mempertanyakan unsur pembangun puisi, dan mengumpulkan informasi terkait unsur pembangun puisi dilakukan dengan diskusi kelompok dan setiap anggota kelompok sudah bisa bekerja maksimal. Penggunaan pendekatan saintifik dalam perkuliahan Pengantar Ilmu Sastra, selain dapat meningkatkan kualitas perkuliahan juga dapat meningkatkan karakter jujur, tanggung jawab, disiplin, kerja keras, dan kreatif yang terlatih melalui kegiatan diskusi kelompok. 


\section{SIMPULAN}

Implementasi pendekatan saintifik dalam perkuliahan Pengantar Ilmu Sastra dengan lesson study dapat meningkatkan kualitas perkuliahan dan keaktifan mahasiswa dalam perkuliahan. Dalam perkuliahan, mahasiswa menjadi lebih aktif, suasana perkuliahan menjadi lebih kondusif, diskusi kelompok dalam pendekatan saintifik menjadi lebih hidup karena semua anggota kelompok mempersiapkan materi diskusi dengan baik. Tahapan lima M dalam pendekatan saintifik secara keseluruhan dapat meningkatkan peran aktif setiap mahasiswa dalam proses perkuliahan. Mereka juga menjadi lebih antusias dan aktif dalam setiap perkuliahan. Perkuliahan yang dilakukan juga dapat meningkatkan karakter jujur, tanggung jawab, disiplin, kerja keras, dan kreatif. Dengan kualitas perkuliahan yang lebih baik, pemahaman mahasiswa terhadap proses perkuliahan di perguruan tinggi menjadi baik dan pemahaman materi perkuliahan juga menjadi lebih baik.

\section{Ucapan Terima Kasih}

Artikel ini diangkat dari penelitian yang telah dilakukan pada tahun 2015 dengan anggaran DIPA UNY. Oleh karena itu, ucapan terima kasih kepada ketua BPPF yang telah menyetujui dan mendanai penelitian ini. Ucapan terima kasih juga disampaikan kepada kedua orang review yang telah membaca, mengoreksi, dan memeberi masukan terhadap artikel ini.

\section{DAFTAR PUSTAKA}

Kementerian Pendidikan dan Kebudayaan, Direktorat Pembinaan Sekolah Menengah Pertama. 2014. Panduan Penguatan Proses Pembelajaran Sekolah Menengah Pertama. Jakarta.

Permendikbud No. 65 Tahun 2013 tentang Standar Proses Pendidikan Dasar dan Menengah.

Pusat Penjaminan Mutu. 2014. "Program Perluasan Lesson Study di FBS Universitas Negeri Yogyakarta" Laporan Kegiatan Monitoring dan Evaluasi. Yogyakarta: Lembaga Pengembangan dan Penjaminan Mutu Pendidikan UNY.

Sukirman. 2013. "Upaya Meningkatkan Mutu Perkuliahan pada Perguruan Tinggi Melalui Lesson Study". Makalah. Yogyakarta: UNY.

Suwarna, dkk. 2014. "Implementasi Lesson Study sebagai Upaya Peningkatan Kualitas Perkuliahan di Fakultas Bahasa dan Seni Universitras Negeri Yogyakarta" Kumpulan Artikel Seminar Lesson Study. Yogyakarta: FBS UNY. 